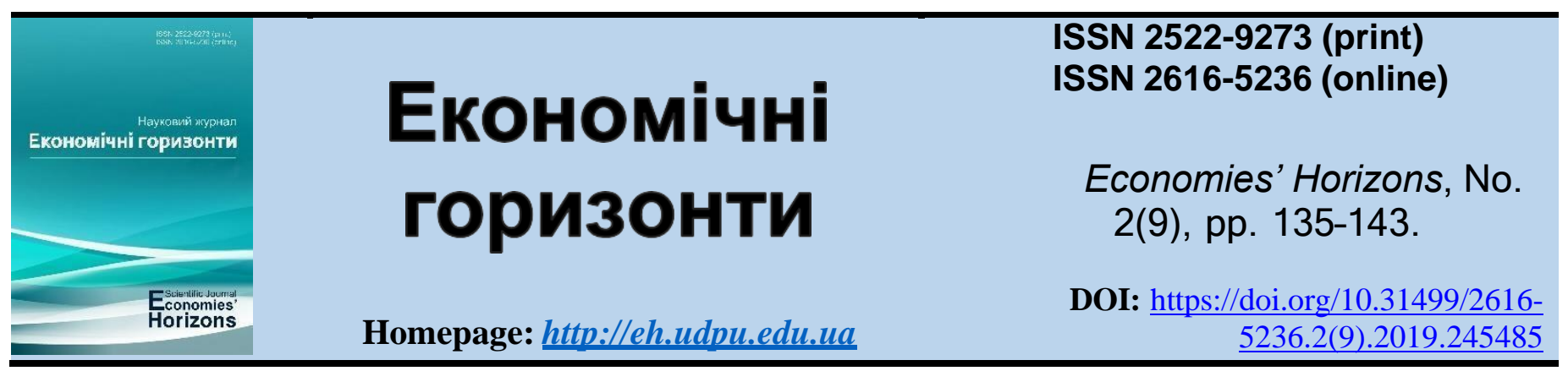

UDC 332.146:330

JEL Classification: E27, H41, H70

\title{
Directions for improving the mechanism of sustainable development management in the region in terms of decentralization
}

\section{N.V. Osadchuk ${ }^{1}$, postgraduate}

Abstract. The aim of the study. The purpose of the article is to improve the management mechanism of sustainable development of the region in the context of decentralization. Methodology. The article uses systematic analysis, tabular and graphical - in the study of improving the mechanism of management of sustainable development of the region in the context of decentralization. Results. It is argued that the implementation of the proposed concept of sustainable development in the region in decentralization will increase social and economic opportunities in the region, ensure environmental security, help neutralize internal and external threats and risks and generally have a positive impact on sustainable development by balancing competitive advantages. The proposed approach allows to assess the change of economic, social and environmental, political parameters for sustainable development of the region under the influence of different levels of regional capacity: high, medium and low and to predict the level of regional development. ensure the balance of goals, results, interests of regional development management, balancing the system of indicators, which, in turn, is an effective management tool that achieves sustainable development of the region on the basis of planned strategic plans, using operational management and monitoring strategy implementation. based on key performance indicators, which is the final stage of the process of managing sustainable development of the region, and allows you to assess changes in economic, social, environmental and political parameters, their impact on the integrated indicator and conduct a comparative analysis of development of regions. The practical significance of the study is that the mechanism developed in the management of sustainable development of the region in the context of decentralization can be used in the activities of local governments. Prospects for further research. It is determined that the use of this mechanism will allow public authorities to increase the effectiveness of program activities by changing such parameters as the level of available resources, the

\footnotetext{
${ }^{1}$ Uman State Pedagogical University named after Pavel Tychyna; senior lecturer at the Department of Finance, Accounting and Economic Security; identifier ORCID: https://orcid.org/0000-0001-5921-3869; e-mail: 
dynamics of their costs, the life cycle of their implementation and priorities of individual activities.This will allow regulating the maximum amount of funding based on the annual development forecasts of the region.

Keywords: sustainable development, region, sustainable development of the region, mechanism for managing sustainable development of the region, decentralization.

Number of references: 10; number of tables: 1; number of figures: 1 ; number of formulas: 0

\section{Напрями вдосконалення механізму управління сталим розвитком регіону в умовах децентралізації}

\section{Н. В. Осадчук ${ }^{1}$, аспірант}

Анотація. Мета дослідження. Мета статті полягає в удосконаленні механізму управління сталим розвитком регіону в умовах децентралізації.

Методологія. У статті використано системний аналіз, табличний та графічний - при дослідженні вдосконалення механізму управління сталим розвитком регіону в умовах децентралізації.

Результати. Аргументовано, що реалізація запропонованої концепції управління сталим розвитком регіону в умовах децентралізації дозволить підвищити соціальні та економічні можливості регіону, забезпечить екологічну безпеку, сприятиме нейтралізації внутрішніх та зовнішніх загроз та ризиків й загалом позитивно впливатиме на сталий розвиток регіону збалансувавши конкурентні переваги. Запропонований підхід дозволяє оцінити зміну економічних, соціальних та екологічних, політичних параметрів на сталий розвиток регіону під дією різних рівнів спроможності регіону: високого, середнього та низького та спрогнозувати рівень розвитку регіону, що, на відміну від існуючих, передбачає побудову індикативної моделі використовуючи інструменти, що забезпечують збалансованість цілей, результатів, інтересів суб'єктів управління регіональним розвитком, збалансувавши систему показників, яка, в свою чергу, $є$ ефективним інструментом управління, що дозволяє досягти сталого розвитку регіону на основі планомірно реалізованих стратегічних плани, використовуючи операційне управління та контролюючи реалізацію стратегії на основі ключових показників ефективності діяльності, що є заключним етапом процесу управління сталим розвитком регіону, та дозволяє оцінити зміну економічних, соціальних, екологічних та політичних параметрів, їх вплив на інтегральний показник та провести порівняльний аналіз розвитку регіонів.

Практичне значення дослідження полягає в тому, що розроблений у роботі механізму управління сталим розвитком регіону в умовах децентралізації може бути використаним у діяльності органів місцевого самоврядування.

\footnotetext{
${ }^{1}$ Уманський державний педагогічний університет імені Павла Тичини; стариий викладач кафедри фінансів, обліку та економічної безпеки; ідентифікатор ORCID: https://orcid.org/0000-0001-5921-3869; $e$ mail:n.osadchuk@udpu.edu.ua
} 
Перспективи подальших досліджень. Визначено, що використання даного механізму дозволить органам публічного управління підвищити ефективність програмних заходів за рахунок зміни таких параметрів, як: рівень наявних ресурсів, динаміка їх витрат, життєвого циклу їх реалізації та пріоритетів окремих заходів. Це дозволить регулювати граничні обсяги фінансування виходячи з щорічних прогнозів розвитку регіону.

Ключові слова: сталий розвиток, регіон, сталий розвиток регіону, механізму управління сталим розвитком регіону, децентралізація.

Кількість джерел: 10; кількість таблиць:1;кількість рисунків: 1; кількість формул:0

\section{Introduction.}

Sustainable development of the region is the main concept and strategic goal of economic management not only of the regions, but also of the country as a whole. It should, on the one hand, be based on global factors and, on the other hand, take into account the specific features of each region, its transport, natural, economic, social and other conditions, human and labor potential - that is, all that ensures continuous reproduction mandatory requirements of the doctrine of sustainable development.

Of particular note is the study of the potential of communities to achieve a balanced development of territories and regions. Solving this problem also requires the development of a methodology for assessing the region's capacity for decentralization.

Given the scientific achievements of scientists and taking into account the important theoretical and methodological bases for solving the outlined problems, the issues of ensuring effective management of sustainable development of the region in decentralization remain insufficiently addressed, as changing the powers of public administration the region's capacity to achieve balanced and sustainable development. The urgency of the above problems led to the choice of topic, determined the purpose of the study.

\section{Literature review.}

The issues of adaptation of the concept of sustainable development to domestic conditions, formation and implementation of state and regional policy of sustainable development, mechanisms of its economic support are investigated in the works: Dolishniy M.I. (2006), Knogler M., Sekarev O. (1995), Mihus, I. \&GrebenS. (2020). Prokopyuk A. In their works the state regional policy as one of tools and directions of activization of sustainable development of regions of Ukraine is investigated. It should be noted that this tool is not a panacea, but acts as an additional stimulus to the development of the social component of regional policy.

\section{Methodology.}

The article uses systematic analysis, tabular and graphical - in the study of improving the management mechanism of sustainable development of the region in terms of decentralization.

\section{Research objectives.}

The aim is to find ways to improve the mechanism of sustainable development management of the region in the context of decentralization.

\section{Results and discussions.}


Analyzing the scientific works of domestic and foreign scientists, the main approaches to the interpretation of the concepts of "region", "sustainable development of the region" and "management of sustainable development of the region" are systematized. Research and systematization of the theoretical foundations of regional development has shown that existing interpretations of this concept do not fully reveal its essence, defining the "region", primarily as part of the country. The study proposes to define the term "region" as a system consisting of interacting complexes (economic, social, environmental, political) that operate in interconnection and interdependence in a given area and ensure its development.

At the same time, "sustainable development of the region" is considered as: systemic - focused on the interests and potential of man and society in general, adaptive in nature and qualitative in nature, targeted changes, accompanied by increased economic, social, environmental efficiency under certain political conditions and are stable both to previous invariant states and to the achievement of rational models of sustainability at different stages of evolutionary development; positively directed process of improving the economic, social and environmental component, and - as the process of achieving a balanced state of all these components while the state regional policy plays a leading role in the context of institutional change. It was found that "sustainable development management of the region" is the ability of the system: to achieve the planned values of indicators of accelerated sustainable development; to maintain the goals of sustainable development, to quickly return to its original state in case of violation of stability; maintain equilibrium during structural transformations within each of the subsystems (managed and control subsystems).

To form a holistic theoretical picture of the study features and principles of sustainable development management in the region in decentralization, using a systematic approach identified its main elements and developed a structural and logical scheme of sustainable development management in the region in decentralization.

It is established that resource provision is the "initial state" of the management system. Once in the managed subsystem, these resources are transformed into the capacity of the region, which helps to achieve the goals of sustainable development through the interaction of four key components - economic, social, environmental and political spheres. The management subsystem is characterized by a set of regional and state authorities, which, when making decisions at the regional level, can influence the processes without violating the principles of hierarchy, system and integrity. Therefore, each of the subsystems needs adequate instrumental and methodological support for monitoring and evaluation of sustainable development components, which would take into account the requirements of all stakeholders (stakeholders of the system) and would fully reflect the balanced development of system components (economic, environmental, social). in general. Monitoring and assessment (information subsystem) of the state of sustainable development will determine its level (integrated assessment) and is the final stage of the management system.

The study of methodological approaches to assessing the state of sustainable development of the region 
confirmed the lack of a unified systematic approach to such assessment. Based on the functional components of the structural and logical scheme of sustainable development management in the region in terms of decentralization, it was determined that the main tool that affects on the basis of complex indicators and the effectiveness of assessing internal and external social, economic, environmental capabilities of the region. ultimately, allow to achieve strategic and tactical goals, while influencing the formation of management decisions to increase the capacity of the region in order to achieve balanced and sustainable development.

The study of modern approaches to sustainable development management of the region necessitated the author's interpretation of the concept of "conceptual principles of sustainable development of the region" based on the objectives of spatial organization of social relations, balanced between the interests of the region, between social and economic opportunities; focused on improving the energy efficiency of the region and ensuring environmental security and environmental management; optimally taking into account economic and environmental interest.

A conceptual approach to sustainable development management in the region in the context of decentralization, based on the assessment and balancing of competitive advantages - social, economic, environmental and political, influenced by internal and external factors, by setting goals, principles, functions, methods and tools of sustainable development; identification of objects, subjects of management and factors of influence, as well as the development and use of algorithms for making managerial decisions to ensure sustainable development of the region in accordance with three prognostic scenarios of development (pessimistic, realistic, optimistic).

To ensure the achievement of sustainable development goals of the region, the mechanism of sustainable development management in the region of decentralization has been improved and tested, which includes a set of principles, functions, methods and tools under which controlled and partially controlled factors of balanced regional development are assessed. and the external environment in the dynamics of forecasting the achievement of planned indicators of sustainable development of the region, which is determined by: indicators of development goals in each identification space and ensure coordination of links between the elements; structural processes; ways to balance contradictions, including political, in spatial, temporal and functional aspects; the substantive aspect of which is represented by goals, functions, principles (Fig.1).

The issues of adaptation of the concept of sustainable development to domestic conditions, formation and implementation of state and regional policy of sustainable development, mechanisms of its economic support are investigated in the works: Dolishniy M.I. (2006), Knogler M., Sekarev O. (1995), Mihus, I. \&GrebenS. (2020). Prokopyuk A.

Based on the analysis of the state and trends of socio-economic development of the central regions of Ukraine, its strengths and weaknesses were identified, which create the preconditions for the formation of a mechanism for effective development of the region's economy through its financial resources. In the framework of the dissertation, to determine the level of economic development of the central 
regions of Ukraine in comparison with indicators, which are most often given in other subjects used such socio-economic official statistical collections.

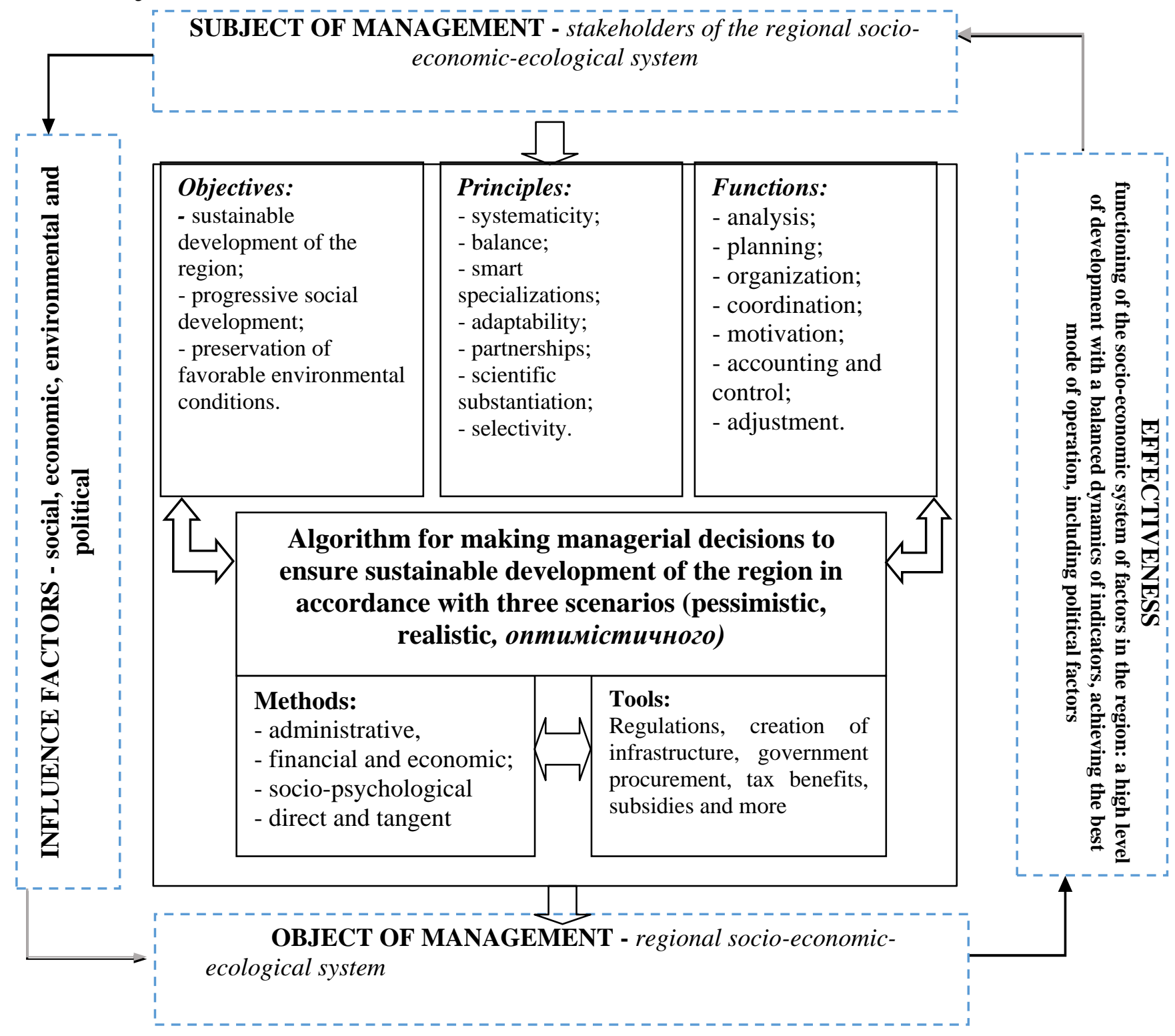

Fig. 1 Mechanism for managing sustainable development of the region in the context of decentralization

Source: compiled by the author

The proposed methodological approach involves the calculation of indicators of economic, social, environmental and political components of sustainable development of the region based on the system of indicators for assessing sustainable development of the region (Table 1).

The dynamic growth of the integrated indicator will be evidence of sustainable development of the regional system and will be reflected in a steady positive trend. 


\section{Table 1}

An integrated indicator of sustainable development of the region in the context of decentralization

Indexes

\begin{tabular}{|c|c|c|c|}
\hline \multirow{11}{*}{ 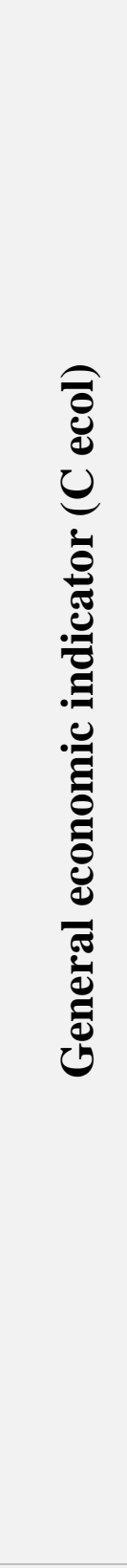 } & $\begin{array}{c}\text { GRP per capita } \\
\text { Average per capita } \\
\text { income of the population }\end{array}$ & \multirow{11}{*}{ 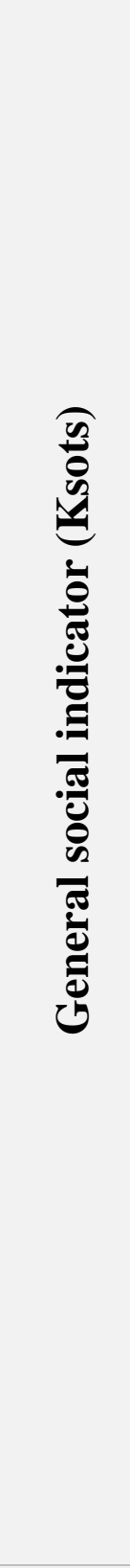 } & $\begin{array}{l}\text { Number of unemployed } \\
\text { Unemployment rate }\end{array}$ \\
\hline & $\begin{array}{l}\text { Average monthly salary } \\
\text { of employees }\end{array}$ & & $\begin{array}{l}\text { Consumer spending in general } \\
\text { per capita }\end{array}$ \\
\hline & $\begin{array}{l}\text { Commissioning of the } \\
\text { total area of residential } \\
\text { buildings }\end{array}$ & & $\begin{array}{l}\text { The population with a cash } \\
\text { income is below the subsistence } \\
\text { level }\end{array}$ \\
\hline & Fixed capital investment & & $\begin{array}{l}\text { The share of household } \\
\text { expenditures on housing and } \\
\text { communal services }\end{array}$ \\
\hline & $\begin{array}{l}\text { Share of fixed capital } \\
\text { investment in GRP }\end{array}$ & & $\begin{array}{l}\text { The share of education } \\
\text { expenditures in total budget } \\
\text { expenditures }\end{array}$ \\
\hline & The subsistence level & & $\begin{array}{l}\text { The share of health care } \\
\text { expenditures in total budget } \\
\text { expenditures }\end{array}$ \\
\hline & Retail turnover per capita & & $\begin{array}{l}\text { Expenditures of budgets for } \\
\text { the implementation of measures of } \\
\text { social support for certain categories } \\
\text { of citizens }\end{array}$ \\
\hline & $\begin{array}{l}\text { Internal expenditures on } \\
\text { research and development }\end{array}$ & & $\begin{array}{l}\text { Number of registered crimes } \\
\text { per } 100,000 \text { population }\end{array}$ \\
\hline & $\begin{array}{c}\text { Share of research and } \\
\text { development expenditures in } \\
\text { GRP }\end{array}$ & & \multirow{3}{*}{$\begin{array}{l}\text { Incidence per } 1,000 \\
\text { population }\end{array}$} \\
\hline & The cost of fixed assets & & \\
\hline & $\begin{array}{c}\text { The degree of } \\
\text { depreciation of fixed assets }\end{array}$ & & \\
\hline \multirow{4}{*}{ 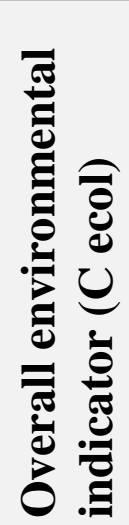 } & $\begin{array}{c}\text { The share of } \\
\text { environmental expenditures in } \\
\text { the regional budget }\end{array}$ & \multirow{4}{*}{ 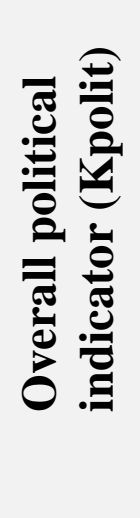 } & Forecast of political changes \\
\hline & $\begin{array}{l}\text { Emissions of pollutants } \\
\text { into the atmosphere }\end{array}$ & & State subsidies \\
\hline & $\begin{array}{c}\text { Discharge of polluted } \\
\text { wastewater into water bodies }\end{array}$ & & Corruption and bureaucracy \\
\hline & Capture of air pollutants & & $\begin{array}{l}\text { Russia's armed aggression } \\
\text { against Ukraine }\end{array}$ \\
\hline
\end{tabular}

Source: compiled by the author 
The proposed approach allows to assess the change of economic, social and environmental, political parameters for sustainable development of the region under the influence of different levels of regional capacity: high, medium and low and to predict the level of regional development. ensure the balance of goals, results, interests of regional development management, balancing the system of indicators, which, in turn, is an effective management tool that achieves sustainable development of the region on the basis of planned strategic plans, using operational management and monitoring strategy implementation. based on key performance indicators, which is the final stage of the process of managing sustainable development of the region, and allows you to assess changes in economic, social, environmental and political parameters, their impact on the integrated indicator and conduct a comparative analysis of development of regions. And the formed algorithm of realization of the mechanism of management of sustainable development of region in the conditions of decentralization, allows to increase efficiency of program actions at the expense of change of such parameters, as: level of available resources and dynamics of their realization expenses; priority of certain measures, which complements the set of tools to stimulate the sustainable development of regions, taking into account the three forecast scenarios of development (pessimistic, realistic, optimistic) of the region.

Conclusion.

Thus, to ensure the achievement of sustainable development goals of the region, a mechanism for managing sustainable development of the region in the context of decentralization has been developed and tested, which includes a set of principles, functions, methods and tools under which society) and is based on the assessment of controlled and partially controlled factors of balanced regional development in the internal and external environment in the dynamics of forecasting the achievement of planned indicators of sustainable development of the region, which is determined by: indicators of development goals in each identification space; structural processes; ways to balance contradictions, including political, in spatial, temporal and functional aspects; substantive aspect which is represented by goals, functions, principles. It is established that the existing management system in the region takes into account the effectiveness of the industry in terms of the level of implementation of its functions, the criteria for technical and economic indicators.

This approach is incomplete, it does not contribute to the sustainable development of the region, as it considers the indicators of the industry itself and does not take into account the impact of industry activities on the external environment, ie intersectoral cooperation. In this regard, the author substantiates the feasibility of using an indicative approach to sustainable development management. The structural and logical scheme of sustainable development management of the region is developed and presented, which is aimed at ensuring the stability of the regional system. It is based on the system of indicators proposed in the work, which allows to assess the effectiveness of sustainable development management from the standpoint of end users and taking into account intersectoral interaction.

Improving methodological tools for assessing the level of development of the 
region, which, unlike existing ones, involves building an indicative model using tools that balance the goals, results, interests of regional development management, balancing a system of indicators, which in turn is effective management tool that allows to achieve sustainable development of the region on the basis of systematically implemented strategic plans, using operational management and monitoring the implementation of the strategy based on key performance indicators, which is the final stage of sustainable management of the region. It is argued that the implementation of the proposed concept of sustainable development management in the region in terms of decentralization will increase social

\section{The Cabinet of Ministers of Ukraine. Resolution No 695. URL:https://zakon.rada.gov.ua/laws/show/695-2020-п\#Text2.}

Dolishniy M.I. (2006). Regional policy at the turn of theXX-XXI century: new priorities. $-\mathrm{K}$.: Scientific opinion. $512 \mathrm{p}$.

Knogler M., Sekarev O. (1995), Market reform and regional policy.Economy of Ukraine.No 1. P.64-71

Prokopyuk A., State regional policy: scientific approaches and world practices. URL:http://ird.gov.ua/sep/sep20156(116)/sep20156(116)_014_ProkopiukA.pdf

Ukraine: a year afterthe election. Monitoring of regions / According to the general. ed. I.O. Roe deer; Laboratory of Legislative Initiatives. K .; Lviv: MS, 2007. 336 p.

State Fund for Regional Development (SFRD) URL:https://dfrr.minregion.gov.ua/prokonkurs

Decentralization and formation of regional development policy in Ukraine (2020), for science. ed. Ya. A. Zhalila. -153 p.URL:https://niss.gov.ua/sites/default/files/202009/decentralizatsiya-i-formuvannya-polityky-regionalnogo-rozvytku-vukraini_0.pdf

State Fund for Regional Development.URL:https://dfrr.minregion.gov.ua

On approval of the State Strategy for Regional Development for 2021-2027 URL:https://zakon.rada.gov.ua/laws/show/695-2020-p\#Text

Improving the functioning of the State Fund for Regional Development URL:https://niss.gov.ua/sites/default/files/2020-09/dfrr.pdf

Mihus, I. \&GrebenS (2020), Modern approaches to the essence and forms of public administration. DOI:https://doi.org/10.36690/PADE-06.Received: November 11, 2020Approved: December 04, 2020 